\title{
MEMBANGUN PEMAHAMAN TERHADAP KARYA SASTRA BERBENTUK FIKSI (TELAAH SIFAT DAN RAGAM FIKSI NARATIF)
}

\author{
Siti Musyarofah \\ Sekolah Menengah Pertama Negeri 3(SMPN3) Babat \\ Kab.Lamongan Telp.(0322) 452725/085231020040 \\ Email: siti.musyarofah17@yahoo.coom
}

\begin{abstract}
Some people who appreciate literature still discuss about the real of each terms which often appear in literary works especially in narrative fiction, such as plot, story, character, characterization, and conflict. Eventhough, there are some people who appreciate literature who are not able to differentiate those terms. That is why, the purpose of this article is to explain the position of literary works in fiction, especially narrative fiction. Because of characteristic of fiction include all the aspects of story so in this article explain about story, plot, and conflict. Story as an even which followed by other even, then followed by another even, and so on, while plot as even series which is composed by cause and effect. Meanwhile, conflict is created by the interaction of each character. Without interaction, a conflict could not be created. So that is why, a conflict as a part of integral that should be stated in. Good or bad o a conflict depend on the criteria of conflict itself.
\end{abstract}

Keywords: fiction, narrative, plot, story, character, characterization, conflict.

\begin{abstract}
Abstrak: Sebagian penikmat sastra masih mempertanyakan tentang kejelasan masingmasing istilah yang sering muncul dalam karya sastra berbentuk fiksi naratif, semisal plot, cerita, tokoh, penokohan, watak, perwatakan, karakter, karakterisasi dan konflik. Bahkan, ada di antara penikmat sastra tersebut yang tidak mampu membedakan istilahistilah tersebut. Oleh karena itu, artikel ini bertujuan untuk menjelaskan posisi karya sastra berbentuk fiksi, terutama fiksi naratif. Oleh karena sifat fiksi naratif mencakupi semua unsur penceritaan maka dalam artikel ini dijelaskan tentang keberadaan cerita, plot, dan konflik. Cerita merupakan sebuah peristiwa yang diikuti oleh peristiwa lain, lalu diikuti oleh peristiwa lagi, dan seterusnya, sedangkan plot merupakan rangkaian peristiwa yang diikat oleh sebab akibat. Konflik sementara itu, tercipta karena interaksi antartokoh. Tanpa interaksi konflik tidak akan tercipta. Oleh karena itu, konflik merupakan bagian integral yang harus ada. Baik buruknya sebuah konflik ditentukan oleh kreteria konflik sendiri.
\end{abstract}

Kata kunci: fiksi naratif, plot, tokoh, konflik

\section{PENDAHULUAN}

Apresiasi terhadap karya sastra yang berbentuk fiksi naratif tidak begitu banyak dibandingkan dengan karya sastra bentuk lain, semisal pantun, puisi, gurindam dan lain-lain. Demikian pula teori dan kritik sastra yang membahas novel, lebih sedikit dan lebih rendah mutunya dibandingkan dengan teori dan kritik puisi (Wellek dan Warren, 1993:276), dan para sastrawan yang mengambil jalan sebagai kritikus pun 
jarang kita jumpai dalam kritiknya terhadap karya sastra berbentuk fiksi naratif. Menurut Wellek dan Warren (1993:276) penyebab semua itu karena asosiasi yang parsial terhadap karya sastra yang berbentuk fiksi naratif. Selama ini karya sastra semacam novel dianggapnya sebagai karya sastra hiburan dan pelarian, bukan dianggap sebagai karya sastra yang serius. Mereka menyamaratakan novel-novel besar karya orang-orang terkenal dunia dengan novelnovel yang berorientasi pasar, dan banyak kita jumpai di toko buku pinggirpinggir jalan.

Di Amerika persepsi negatif terhadap karya sastra fiksi pun (secara umum), telah menjadi-jadi. Para guru di Amerika memberikan stigma sangat negatif terhadap karya sastra ini. Dianggapnya karya sastra bentuk fiksi sebagai karya sastra yang tidak baik, dan hanya akan mengobsesi pada sikap yang malas-malasan. Pandangan yang demikian ini dikuatkan oleh sikap para kritikus yang menonjol di Amerika, semisal Lowell dan Arnold (Wellek dan Warren, 1993:276).

Di sisi lain sebaliknya, ada sebagian orang mempersepsi berlebihan terhadap karya sastra bentuk ini. Semisal, mereka menafsirkan novel terlalu serius dengan cara yang keliru. Novel dianggap sebagai dokumen atau kasus sejarah, karena ditulis dengan serius dan sangat meyakinkan sebagai sebuah cerita kejadian yang sebenarnya, sebagai sejarah hidup seseorang dan zamannya. Persepsi yang demikian itu jelaslah berlebihan, dan mereka tidak memahami dengan benar karakter dari karya sastra, terutama karya sastra berbentuk fiksi naratif. Tentu saja karya sastra harus ditulis dengan menarik, memiliki struktur dan tujuan estetis, koherensi secara keseluruhan dan ada efek tertentu yang ditimbulkan. Ketika membaca karya sastra, mereka harus menyadari bahwa, ia telah berada di alam (dunia) lain, yakni dunia yang tidak nyata, di mana hukum dunia tidak berlaku lagi, hewan bisa bercakap, pohon bisa bergerak, si anak kecil bisa mengalahkan harimau, yang adil dihukum dan yang durhaka mendapat ganjaran, yang benar bisa melenggang dan yang salah dipenjara, singkatnya dunia bisa kita ciptakan, serta awal dan akhir dari kehidupan dunia bisa kita tentukan, lain halnya dengan dunia nyata yang tidak berawal dan berakhir dengan jelas (cf. Teew, 1983:16).

Untuk memberi pengertian dan hakikat tentang fiksi naratif, sebelumnya kita tengok terlebih dahulu makna dari kedua kata itu. Kata fiksi dalam kamus sastra diartikan sebagai khayalan atau sesuatu yang direka (Sujiman, 1990:321). Jika ditautkan dengan karya sastra, fiksi diartikan sebagai karya sastra yang berisi kisahan yang direka, dan pada umumnya terdapat dalam tulisan yang berupa prosa. Bahkan, Nurgiantoro (2005:2) menyebut fiksi tidak hanya cerita rekaan atau cerita khayalan, tetapi setiap prosa dalam pengertian kesastraan disebutnya dengan fiksi.

Sementara itu, naratif adalah kata sifat yang berasal dari kata narasi dan mengandung arti sebagai suatu bentuk wacana, dan sasaran utamanya adalah tindak-tanduk yang dijalin dan dirangkaikan menjadi sebuah peristiwa yang terjadi dalam suatu kesatuan waktu, atau dapat pula diartikan sebagai bentuk wacana yang berusaha menggambarkan dengan sejelas-jelasnya kepada pembaca suatu peristiwa yang telah terjadi (Keraf, 1985:136). Lain lagi dengan pendapat Luxemburg (1989:119) bahwa, naratif dimaknai sebagai teks yang tidak bersifat dialog, yang isinya merupakan suatu kisah sejarah, sebuah deretan peristiwa. Lebih lanjut dikatakan bahwa yang dikategorikan sebagai naratif tidak hanya 
karya yang berbentuk sastra, tetapi dapat pula berupa warta berita, laporan dalam surat kabar atau televisi, berita acara, dan sebagainya.

Merujuk dari pengertian kedua kata tersebut dapat disimpulkan bahwa yang disebut dengan fiksi naratif adalah suatu karya imajiner yang isinya tidak menyaran pada kebenaran sejarah, tetapi menyaran pada sesuatu yang bersifat rekaan, khayalan, sesuatu yang tidak ada dan tidak terjadi sungguh-sungguh, sehingga tak perlu dicari kebenarannya pada dunia nyata. Fiksi selalu dipertentangkan dengan fakta. Oleh karena fiksi adalah khayalan, maka fakta adalah realita, yakni sesuatu yang benar ada dan terjadi di dunia nyata, sehingga kebenarannya pun dapat dibuktikan dengan data empiris (Nurgiantoro, 2005:2).

Sebagai sebuah karya imajiner, fiksi menawarkan berbagai permasalahan manusia dan kemanusiaan, hidup dan kehidupan. Di sinilah para sastrawan menghayati dengan seksama kehidupan alam nyata ini dengan berdialog, berkontemplasi serta berintraksi dengan lingkungan kehidupan, berikutnya disuguhkan kembali melalui paparan fiksi sesuai dengan pandangan mereka tentang kehidupan ini. Oleh karena itu, tak kurang dari seorang Altenbernd dan Lewis (1966:14, dalam Nurgiantoro, 2005:2) memberikan pengertian tentang fiksi naratif sebagai prosa naratif yang bersifat imajinatif, tetapi mengandung kebenaran yang masuk akal (rasional).

Untuk memberikan simpulan terhadap pengertian dan hakekat dari fiksi naratif tersebut, kita perlu mengklasifikasikannya berdasarkan beberapa ciri-ciri yang dimiliki. Bahwa, semua karya sastra yang berbentuk prosa dan ditulis dalam cerita rekaan maka dapat kita masukkan dalam kategori sebagai fiksi naratif. Menurut
Nurgiantoro (2005:2) ada beberapa kategorisasi dari fiksi naratif, yaitu: 1) merupakan karya imajiner dan estetis. Artinya fiksi naratif merupakan karya yang bersifat imajinatif atau khayalan belaka dan mengandung keindahan di dalamnya. Sebagaimana yang dilontarkan oleh Horace (Horatius) bahwa karya seni yang baik, termasuk karya sastra, harus selalu memenuhi dua butir kriteria, yakni dulce et utile (indah dan berguna). Maksudnya karya sastra harus bagus, menarik dan memberi kenikmatan. Tentu saja kenikmatan ini hanya dimiliki oleh pembaca yang bermutu (Darma, 2004:9).

2) kebenaran fiksi. Maksudnya, kebenaran dalam dunia fiksi adalah kebenaran menurut pengarang, tentu kebenaran yang telah diyakini sebagai kebenaran yang "absah" sesuai dengan pandangan pengarang terhadap masalah hidup dan kehidupan, dan kebenaran dalam karya fiksi tidak harus sejalan dengan kebenaran yang berlaku di dunia nyata. Sesuatu yang tidak mungkin terjadi dan tidak dianggap benar dalam dunia nyata, dapat saja terjadi dan dianggap benar dalam dunia fiksi.

Sementara itu, menurut Luxemburg setidaknya ada tiga aspek dalam teks naratif yang perlu mendapat atensi dari pembaca. Ketiga aspek itu ialah: 1) situasi bahasa yang tidak homogen. Artinya bahwa, dalam karya naratif terdapat penutur primer dan sekunder yang merupakan ciri khas bagi jenis ini; 2) wajah dunia (fiktif), bahwa karya sastra naratif berpijak pada dunia khayal si juru cerita; dan 3) susunan dunia (fiktif), adaya deretan peristiwa yang menyangkut hubungan antara para pelaku dengan peristiwa yang terkait dengan mereka.

Oleh karena itu, artikel ini bertujuan untuk menjelaskan posisi karya sastra berbentuk fiksi, terutama fiksi naratif. Oleh karena sifat fiksi narati 
mencakupi semua unsur penceritaan maka dalam artikel ini dijelaskan tentang keberadaan cerita, plot, dan konflik.

\section{SIFAT FIKSI NARATIF}

Menurut Wellek dan Warren (1993:282) pola utama fiksi naratif sifatnya yang mencakup semua unsur penceritaan. Unsur penceritaan dalam suatu fiksi naratif merupakan struktur dari pembentuk cerita. Unsur-unsur itu meliputi, plot (alur), penokohan, dan latar (Wellek dan Warren, 1993:283), sedangkan, menurut Nurgiantoro (2005:10) unsur-unsur pembangun cerita meliputi plot (alur), tema, tokoh, latar, kepaduan, dan lain-lain.

Untuk memahami bagaimana keberadaan unsur-unsur tersebut, berikut ini uraian selengkapnya.

\section{Plot (Alur)}

Plot (alur) dalam fiksi naratif disebut juga jalannya cerita, yakni sebuah peristiwa yang susul-menyusul, atau sebuah peristiwa yang diikuti oleh peristiwa lain, lalu diikuti oleh peristiwa lain lagi, dan seterusnya (Darma, 2004:13). Namun, plot oleh sebagian orang sering disamakan dengan cerita. Kendati dalam praktik cerita dapat bermakna plot, tetapi keduanya terdapat perbedaan. Jika cerita merupakan sebuah peristiwa yang diikuti oleh peristiwa lain, lalu diikuti oleh peristiwa lain lagi, dan seterusnya, maka plot sementara itu, merupakan rangkaian peristiwa yang diikat oleh sebab-akibat.

Untuk membedakan antara cerita dengan plot dapat kita lihat dalam contoh berikut ini.

Contoh cerita: Ketika Ali berangkat dari rumah menuju ke hutan, matahari masih sepenggalah. Sesampainya di hutan posisi matahari sudah di atas kepala, kemudian ia langsung mencari kayu bakar hingga matahari condong ke barat, lalu ia beristirahat sejenak untuk melepas lelah. Selanjutnya, ia bergegas meneruskan mencari kayu bakar tersebut, setelah dirasa cukup, lalu ia pulang. Sesampainya di rumah ia istirahat sejenak untuk mengeringkan keringat, lalu mandi dan makan malam, dan seterusnya.

Contoh plot: Sang Jenderal sakit, karena itu dokter segera dipanggil. Namun, ternyata dokter tidak sanggup menyembuhkan, dan karena itu dipanggillah dokter terkenal dari luar negeri. Ternyata dokter ini pun tidak sanggup menyembuhkan sang jenderal. Sangkit sang jenderal semakin parah, dan karena itu sang istri makin sedih. Pada suatu hari setelah melalui masa-masa kritis, sang jenderal wafat. Karena sang jenderal wafat sang istri bertambah sedih, dan akhirnya ia pun meninggal juga.

Menurut Budi Darma (2005:13), karya sastra yang baik bukan sekedar cerita, melainkan plot, yakni antara satu peristiwa dan peristiwa lain diikat oleh hukum sebab akibat, sedangkan kunci penting sebab akibat tidak lain adalah konflik, dan kunci penting dari konflik adalah tokoh atau penokohan.

Nurgiantoro menambahkan, bahwa plot atau alur cerita tidak harus berisi penyelesaian yang jelas, tetapi penyelesaian diserahkan kepada interpretasi pembaca. Demikian pula urutan peristiwa dapat dimulai dari mana saja tidak harus dimulai dari perkenalan para tokoh atau latar, tetapi bisa juga dimulai dari konflik yang telah meningkat.

Menurut Keraf (1985:148) alur merupakan dasar yang sangat penting dalam kisah. Alur mengatur bagaimana tindakan-tindakan harus bertalian satu sama lain, bagaimana suatu insiden mempunyai hubungan dengan insiden lain, bagaimana tokoh-tokoh digambarkan dan berperan dalam tindakan-tindakan itu, dan bagaimana situasi dan perasaan karakter (tokoh) yang terlibat dalam tindakan-tindakan itu, dan yang terikat dalam suatu kesatuan waktu. Oleh karena itu, baik tidaknya 
penggarapan plot dinilai dari keterjalinan setiap insiden.

\section{Tokoh (Penokohan)}

Menurut Nurgiantoro (2005:165), istilah "tokoh" menunjuk pada orangnya, sedangkan watak, perwatakan, dan karakter lebih menunjuk pada sifat dan sikap para tokoh seperti yang ditafsirkan oleh pembaca, dan lebih menunjuk pada kualitas pribadi seorang tokoh. Adapun penokohan adalah pelukisan gambaran yang jelas tetang seseorang yang ditampilkan dalam sebuah cerita.

Bentuk penokohan yang paling sederhana adalah pemberian nama. Setiap sebutan adalah sejenis cara memberi kepribadian. Ada banyak ragam penokohan dalam fiksi naratif. Seperti yang dilakukan oleh seorang novelis Scot, ia memperkenalkan setiap tokoh dalam satu alinea yang menguraikan secara rinci penampilan fisik tokoh, dan satu alinea lagi untuk mengenali sifat moral dan psikologi tokoh. Lain halnya dengan novelis Dikens, dalam novelnya setiap kali seorang tokoh muncul selalu disertai dengan lagak, gerak, dan cara berbicara khas yang mengikutinya, yang berfungsi untuk menandai watak tokoh. Namun, kadang-kadang ciri yang digunakan untuk menandai tokoh-tokoh bisa saja dengan tanda yang harfiah, misal, seorang tokoh yang bernama Aryo Penangsang dalam lakon "Aryo Penangsang Gugur", selalu dekat dengan pusaka Bromot Setan Kobernya, tokoh yang bernama Kiyai Karnawi dalam cerpen "Kuburan Kyai Karnawi" semasa hidupnya tidak pernah melepaskan tasbih dalam genggaman tangannya, dan sebagainya. Pusaka Bromrot Setan Kober yang selalu bersama dengan Aryo Penangsang dan Tasbih yang selalu dalam genggaman Kyai Karanawi adalah tanda harfiah yang dipunyai oleh kedua tokoh tersebut.
E.M. Foster (Darma, 2004:14) membagi tokoh dalam fiksi naratif menjadi dua, yaitu tokoh bulat (roud character) dan tokoh pipih (flat character). Demikian pula Wellek dan Warren (1993:288), mereka memilah penokohan dengan sebutan penokohan statis dan penokohan dinamis atau berkembang. Tokoh bulat (round character) atau tokoh dinamis (berkembang) mempunyai kemampuan untuk berubah, belajar dari pengalaman, dan menyesuaikan diri dengan keadaan, sedangkan tokoh pipih (flat character), atau tokoh statis sebaliknya, tidak mempunyai kemampuan untuk berubah, belajar dari pengalaman. Mulai dari awal sampai akhir tokoh pipih tidak mengalami perubahan watak sama sekali. Namun, dalam sastra dunia ada tokoh- tokoh yang tampaknya tidak dapat berubah, tetapi pada hakekatnya berubah. Ini dapat kita baca dalam tokoh sentral tragedi Shakespeare Macbeth, misalnya, sejak awal sampai akhir tetap serakah dan kejam. Namun, titik berat keserakahan dan kekejaman terletak pada sifat buruk dia, yaitu ambisi yang berlebihan. Dia ingin menjadi raja, dan karena itu semua orang yang dianggap dapat menghalangi keinginannya harus dimusnahkan.

Ambisi Macbeth baru tampak ketika tiga peri meramalkan dia akan menjadi raja pada suatu saat kelak. Seandainya dia tidak pernah bertemu dengan tiga peri itu, ambisinya akan tetap berkobar, kendati mungkin dengan bentuk dan proses lain. Kemudian, dengan cerdik, tetapi juga licik, bersama isterinya dia membuat rencana dengan cermat untuk menghabisi semua pihak yang ingin menghalangi ambisinya. Tindakan dia bersama isterinya untuk membunuh mereka menunjukkan bahwa dia belajar dari keadaan, dan karena itu dia bukan tokoh pipih. 
Tokoh bulat yang baik harus konsisten dalam setiap perubahannya dan harus mempunyai motivasi yang kuat untuk berubah. Konsistensi Macbeth terletak pada ambisinya, dan ambisi inilah salah satu kunci kekuatan dia sebagai tokoh bulat. Tanpa intraksi antara tokoh, konflik tidak akan tercipta. Oleh karena konflik merupakan bagian integral yang harus ada, maka lahirlah berbagai kreteria untuk menilai sebuah konflik itu buruk atau tidak. Dari berbagai kreteria itu dapat disimpulkan bahwa konflik yang baik adalah konflik dilematis. Artinya tokoh berhadapan dengan dilema yang benar-benar tidak memberi kesempatan untuk melarikan diri.

Contoh konflik yang sangat baik dalam sastra dunia tampak dalam drama tragedi Yunani Kuno Antigone, karya Sophocles. Kilasannya cerita sebagai berikut.

Raja Creon dari Thebes dikisahkan mempuyai dua anak laki-laki dan dua anak perempuan. Dua anak laki-laki ini bermusuhan dalam perang saudara, dan akhirnya dua-duanya tewas dalam peperangan. Oleh Creon salah satu anaknya yang tewas tersebut dianggap pahlawan, sedangkan anaknya yang lain dianggap pengkhianat. Mayat anak yang dianggap pahlawan harus dimakamkan dengan upacara kebesaran, sedangkan mayat anak yang dianggap sebagai pengkhianat harus dilemparkan ke padang terbuka untuk menjadi makanan burungburung liar, tanpa upacara sama sekali. Antigone, anak perempuan tertua, menganggap bahwa dua saudara lakilakinya harus dimakamkan dengan layak, dan karena itu dia mempersiapkan sebuah upacara pemakaman untuk menghormati abangnya yang mayatnya akan dibuang ke padang terbuka tersebut. Creon melarang, dan ia tetap pada pendirianya. Konflik dilematis harus dihadapi oleh Antigone: kalau dia menuruti kehendak ayahnya, maka salah satu mayat abangnya akan dinistakan, dan kalau ia melanggar larangan itu ia akan dihukum dengan hukuman mati.
Konsistensi dan motivasi Raja Creon amat jelas, demikian pula konsistensi dan motivasi Antigone. Sebagai tokoh bulat, Raja Creon dan Antigone sangat memenuhi persyaratan estetika sastra. Konflik dalam drama tragedi ini juga tinggi nilai estetika sastranya, karena dilema Antigone benarbenar tidak mungkin diatasi kecuali dengan jalan kompromi, dan dia menolak untuk berkompromi.

Sebagai konsekuansi keharusan adanya konflik, muncul tuntutan lain, yaitu klimaks sebagai penutup plot. Makin tinggi nilai estetika sebuah konflik, makin tinggi pula nilai estetika sebuah klimaks. Oleh karena klimaks memegang kunci penutup plot, maka karya sastra dengan konflik yang baik dan klimaks yang baik juga akan mempunyai penutup yang baik pula. Contoh klimaks yang baik tampak antara lain dalam cerpen Guy de Maupassant dalam "Kalung". Kilasan ceritanya sebagai berikut.

Mathilda, tokoh sentral dalam cerpen ini bukanlah seorang kaya, tetapi terkenal sebagai wanita rupawan dan selalu berpenampilan menarik. Gaji suaminya tidaklah seberapa. Merasa kurang beruntung karena tidak mungkin hidup mewah, dia berusaha keras untuk bergaul dengan kelas atas, sebuah kelas yang sebetulnya berada di luar jangkauannya. Dengan kepiawaiannya dia dapat diterima dengan baik oleh komunitas kalangan atas. Pada suatu ketika dia mendapatkan undangan untuk menghadiri pesta mewah sebuah keluarga kelas atas. Agar dalam pesta itu tampak anggun, dia meminjam sebuah kalung. Dengan mengenakan kalung pinjaman itu, datanglah dia ke pesta, dan, sesuai dengan harapannya, semua orang mengaggumi keanggunannya. Namun, tanpa diduga, kalung itu hilang. Sebagai seseorang yang berpenampilan anggun dan tampak kaya, dengan sendirinya dia tidak mau mengaku kepada pemilik kalung bahwa dia telah menghilangkan kelungnya. Diam-diam dia berhutang ke sana kemari untuk membeli sebuah kalung yang sangat mahal itu 
dan untuk dikembalikan kepada pemiliknya. Untuk mengembalikan hutanghutangnya, dia harus bekerja keras siang dan malam selama bertahun-tahun. Sekarang dia tampak tua kulitnya yang dahulu mulus kini tampak keriput semua, dan tubuhya pun kini kurus kering. Secara kebetulan pada suatu hari pemilik kalung melihat dia sedang bekerja keras menyapu di pinggir jalan. Kendati dia sudah banyak berubah, tetapi pemilik kalung mengenalinya kembali. Pemilik kalung bukan haya terperanjat melihat penampilannya sekarang, tetapi juga kisahnya mengenai Mathilda sampai menderita seperti itu.

Kalung yang dahulu itu sebenarnya hanyalah kalung imitasi, bukan kalung yang sebenarnya. Oleh karena itu, ketika Mathilda dulu mengembalikan kepada pemiliknya pantaslah pemiliknya tidak begitu peduli. Demikianlah, Mathilda telah menyengsarakan dirinya karena menyangka bahwa kalung yang dihilangkannya dulu itu asli, dan untuk mempertahankan martabatnya dia terpaksa menggantinya dengan kalung asli yang sangat mahal.

Klimaks terjadi ketika kalung hilang. Seandainya kalung tidak hilang, penutup plot tentu akan berbeda. Klimaks, sementara itu, sebagai ekoran dari penokohan yang baik dan konflik yang baik, merupakan suatu kreteria untuk menentukan apakah sebuah karya sastra mutu dari estetikanya dapat dipertanggungjawabkan atau tidak.

Ada satu hal penting lain pada penutup plot cerpen tersebut, yaitu surprise. Mathilda dan pembaca tidak menduga sama sekali bahwa kalung itu hanyalah imitasi, dan karena itu, baik Mathilda maupun pembaca merasa terkecoh. Sementara itu, pemilik kalung juga tidak menduga bahwa kalung yang dikembalikan Mathilda benar-benar asli dan harganya mahal sekali.

Tokoh bulat, konflik, dan klimaks merupakan tuntutan yang harus dipenuhi oleh sebuah karya sastra yang baik. Namun, suprise bukan merupakan tuntutan mutlak. Apakah sebuah surprise dapat menambah nilai estetika atau tidak, tergantung pada hakikat masing-masing karya sastra. Beberapa pendapat justru menunjukkan bahwa surprise dianggap sebagai sebuah kelemahan dalam karya sastra. Sebagaimana yang disinyalemen oleh Kuntowijoyo (Darma, 2004:18) bahwa, salah satu kelemahan sastra Indonesia adalah lemahnya konflik. Menurutnya pengarang tidak mampu menciptakan konflik yang bermakna. Hal ini tidak lain karena pengarang adalah produk masyarakat Indonesia. Sebagaimana kita ketahui bahwa, masyarakat Indonesia cenderung menghindari konflik, sehingga berbagai masalah yang seharusnya dapat diselesaikan, tetapi tidak pernah diselesaikan dan dibiarkan berlarut-larut sampai hilang dengan sendirinya. Contoh konflik yang lemah dapat kita lihat dalam novel Nh. Dini, "Namaku Hiroko". Kilasannya cerita sebagai berikut.

Hiroko adalah seorang gadis desa, melarat, tetapi cantik. Tujuan hidupnya tak lain hanya satu, yaitu hidup dengan mudah, mempunyai banyak uang, tanpa bekerja keras. Dia sama sekali tidak mempunyai pertimbangan moral, ketika dia menyerahkan diri kepada sekian banyak lelaki untuk mendapatkan uang, dengan sendirinya dia sama sekali tidak mengalami konflik batin. Seandainya Hiroko mempunyai prinsip moral yang sangat kuat, tentu dia tidak akan mau menyerahkan diri pada lelaki yang akan menjadikannya perempuan simpanan. Kalau dipaksa untuk menjadi perempuan simpanan tanpa kemampuan untuk melawan pasti dia akan dilanda konflik batin yang hebat. Oleh karena Hiroko tidak mengalami konflik, maka klimaks dan penutup plot yang bermakna pun tidak ada. Dalam fiksi naratif, nilai puitik sangat menentukan baik tidaknya suatu karya sastra. Nilai puitik drama tregedi misalnya, ditentukan oleh tiga faktor utama yang menjadi ukuran. Ketiga faktor itu ialah: pity, terror dan catharsis (Darma, 2004:8). Pity adalah rasa iba atau kasihan penonton atau pembaca pada cerita, terutama tokoh utama dalam cerita. Biasanya tokoh utama mengalami 
penderitaan atau penyiksaan. Tokoh Oedipus misalnya, ketika dia dihanyutkan ke dalam sungai akan menimbulkan pity dari penonton atau pembaca. Terror adalah rasa diteror, rasa takut, rasa ngeri dan sebagainya. Tokoh utama mengalami ketakutan, diteror, atau mengalami kengerian dalam perjalanan hidupnya. Seorang Oedipus ketika mengalami malapeta termasuk ketika dia membutakan matanya sendiri, menimbulkan terror. Kemudian, catharsis adalah rasa lega, atau terbebas dari pity dan terror.

Dalam penokohan, pembedaan tokoh selain yang sudah disebutkan di atas masih ada beberapa jenis penamaan lagi berdasarkan dari sudut mana penamaan itu dilakukan. Berdasarkan sudut pandang peran tokoh-tokoh, seorang tokoh menurut Nurgiantoro (2005:176-178) masih dibedakan atas tokoh utama (central character) dan tokoh tambahan (peripheral character), sedangkan berdasarkan fungsi penampilan tokoh, dibedakan atas tokoh protagonis dan tokoh antagonis. Lebih lanjut Nurgiantoro menjelaskan bahwa, yang disebut dengan tokoh utama (central character) adalah tokoh yang diutamakan penceritaanya dalam sebuah novel (fiksi naratif) yang bersangkutan. Ia merupakan tokoh yang paling banyak diceritakan, baik sebagai pelaku kejadian maupun yang dikenai kejadian, sedangkan yang disebut tokoh tambahan (peripheral character) dalam keseluruhan cerita lebih sedikit dan tidak dipentingkan, serta kehadirannya hanya jika ada keterkaitan dengan tokoh utama, secara langsung maupun tidak langsung. Sementara itu, yang disebut dengan tokoh protagonis adalah tokoh yang dikagumi atau tokoh populer (hero). Keberadaanya merupakan pengejawantahan normanorma, nilai-nilai, yang ideal bagi kita (Altenberd dan Lewis, 1966:56, dalam
Nurgiantoro, 2005:178), dan selalu menampilkan sesuatu yang sesuai dengan pandangan kita, harapan-harapan kita (pembaca). Bahkan, kita sering menempatkan diri seakan-akan sebagai dia (tokoh utama). Semua persoalan yang dihadapi, seolah-olah juga sebagai permasalahan kita, demikian pula halnya dalam menyikapinya, sedangkan tokoh antagonis sering disebut sebagai tokoh oposisi, atau tokoh penyebab terjadinya konflik.

Dalam sebuah fiksi naratif tokoh antagonis adalah tokoh yang dibenci oleh pembaca, karena dianggap sebagai sumber petaka dan sumber bencana.

\section{Latar (Setting)}

Latar adalah segala keterangan mengenai waktu, ruang, dan suasana terjadinya lakuan dalam karya sastra (Sujiman, 1990:48). Keberadaan latar dapat menimbulkan kesan tertentu kepada pembaca. Misalnya, suasana rumah yang bersih, teratur, rapi, tidak ada benda-benda yang mengganggu pandangan, maka akan menimbulkan kesan bahwa pemilik rumah itu adalah orang yang cinta kebersihan, lingkungan, teliti, teratur dan sebagainya. Sebaliknya, rumah yang kotor, jorok, barang-barang berserakan di rumah, maka akan memberikan kesan bahwa si pemilik rumah adalah tipe orang yang awutawutan, dan kepribadiannya pun tidak jauh dari itu.

Menurut Nurgiantoro (2005:227) latar dapat dibedakan ke dalam tiga unsur pokok. Ketiga unsur itu ialah: 1) latar tempat; 2) latar waktu; dan 3) latar sosial. Latar tempat menyaran pada lokasi terjadinya peristiwa yang diceritakan. Latar waktu berhubungan dengan masalah "kapan" peristiwa-peristiwa yang diceritakan itu terjadi, dan latar sosial menyaran pada hal-hal yang berhubungan dengan perilaku kehidupan 
sosial masyarakat di suatu tempat yang diceritakan dalam karya fiksi tersebut. Dalam latar sosial tata cara kehidupan masyarakat tercakup di dalamnya. Misalnya, kebiasaan hidup, adat istiadat, tradisi, keyakinan, pandagan hidup, cara berpikir, bersikap, dan sebagainya.

\section{RAGAM FIKSI NARATIF}

Bila kita mengacu pada pengertian fiksi naratif, maka tidaklah sulit bagi kita untuk mengidentifikasi ragam fiksi naratif tersebut. Sebagaimana yang disebut dalam paparan sebelumnya bahwa, fiksi naratif adalah suatu karya imajiner yang isinya tidak menyaran pada kebenaran sejarah, tetapi menyaran pada sesuatu yang bersifat rekaan, khayalan, sesuatu yang tidak ada dan tidak terjadi sungguh-sungguh. Dengan demikian, jenis-jenis karya rekaan yang ditulis dalam bentuk prosa maka dapat digolongkan ke dalam ragam fiksi naratif. Novel (roman), cerita pendek, drama, malahan puisi pun yang berbentuk naratif dianggap sebagai ragam fiksi naratif.

Untuk mengetahui masing-masing bentuk kategori fiksi naratif tersebut selengkapnya dijelaskan dalam paparan berikut ini.

\section{Novel}

Menurut Sujiman (1990:55) novel diartikan sebagai prosa rekaan yang panjang, yang menyuguhkan tokoh-tokoh dan menampilkan serangkaian peristiwa dan latar secara tersusun. Lebih lanjut Sujiman mengatakan bahwa, novel dianggap sebagai istilah lain dari roman. Novel bersifat realistis, dan berkembang dari bentuk-bentuk naratif nonfiksi, misalnya surat, jurnal, memoar atau biografi, kronik atau sejarah. Novel mementingkan detil dan bersifat mimesis (Wellek dan Warren, 1993:283).

Selain itu, tokoh-tokoh dalam novel biasanya ditampilkan secara lengkap, misalnya, yang berhubungan dengan ciriciri fisik, keadaan sosial, tingkah laku, sifat, kebiasaan, dan lain-lain, termasuk bagaimana hubungan antartokoh itu, baik dilukiskan secara langsung maupun tidak. Novel tidak terikat pada panjangnya cerita. Pengarang diberi kebebasan untuk menuangkan segala gagasan tanpa batas. Umumnya novel tidak hanya satu plot, tetapi dapat terdiri dari satu plot utama dan sub-subplot. Plot utama berisi konflik utama yang menjadi inti persoalan yang diceritakan sepanjang karya itu, sedangkan sub-subplot adalah berupa munculnya konflik-konflik tambahan yang bersifat menopang, mempertegas, dan mengidentifikasi konflik utama untuk sampai ke klimaks. Plot tambahan tersebut berisi konflik-konflik yang mungkin tidak sama kadar kepentingannya atau perannya terhadap plot utama. Masing-masing subplot berjalan sendiri-sendiri, malahan mungkin sekaligus dengan penyelesaian sendiri pula, tetapi tetap berkaitan antara satu dengan yang lain, dan tetap dalam hubungannya dengan plot utama.

Novel umumnya terdiri dari sejumlah bab dan masing-masing bab berisi cerita yang berbeda. Hubungan antarbab, kadang-kadang merupakan hubungan sebab akibat, atau hubungan kronologis biasa. Bab yang satu merupakan kelanjutan dari bab-bab yang lain. Oleh karena itu, membaca satu bab dalam novel secara acak, maka kita tidak akan mendapatkan cerita yang utuh, karena keutuhan cerita sebuah novel berada dalam keseluruhan bab.

Tambahan lagi, banyak orang ingin mengklasifikasikan jenis novel ke dalam novel serius dan novel populer atau novel hiburan. Namun, pembedaan itu hanya akan menghasilkan sesuatu yang subjektif saja. Menurut Budi Darma 
karya sastra jenis pop (populer) maupun karya sastra serius (sastra interpretatif) adalah sama-sama karya sastra. Keduanya tetap dianggap sebagai karya sastra. Bahkan, dalam kajian ekstrinsik juga tidak menafikan sastra pop, sebab bagaimanapun sastra pop lebih langsung menggambarkan realita masyarakat daripada sastra serius pada umumnya (Darma, 2004:23). Bahkan, sastra pop, masih menurut Budi Darma, biasanya menggambarkan kehidupan yang mudah dan mewah, tidak lain adalah pencerminan mimpi pembaca mengenai kehidupan, yang dalam kehidupan seharihari sulit dicapai. Sebagaimana dijelaskan oleh beberapa ahli sastra bahwa, di antara fungsi sastra adalah sabagai sarana untuk melarikan diri dari kepahitan hidup, kejenuhan hidup, dan sebagainya. Sungguhpun demikian, perbedaan dari kedua karya sastra itu tetap saja ada. Kebiasaan yang dapat kita kenali dari perbedaan kedua karya sastra tersebut terletak pada kedalaman isi. Karya sastra serius atau sastra interpretatif mendorong pembaca untuk termenung. Lihat saja dalam cerpen Leo Tolstay "Tuhan Tahu, Tetapi Menunggu". Singkat ceritanya sebagai berikut.

Seorang saudagar yang berhati mulia besok pagi harus pergi ke sebuah kota yang jauh untuk memenuhi janji. Tiba-tiba istrinya ditimpa oleh sebuah mimpi buruk. Dalam mimpinya suaminya melakukan perjalanan jauh dan ditimpa oleh musibah, dan akhirnya meninggal dengan tidak hormat. Karena mimpi itu, istrinya memohon kepada sang suami untuk membatalkan niatnya pergi jauh. Namun, bagi saudagar itu, janji adalah janji dan mau tidak mau harus dipenuhi. Maka, dengan mengabaikan nasihat istrinya berangkatlah dia dengan naik kuda. Pada suatu malam ketika dia sedang tidur dengan nyenyak di sebuah rumah penginapan, terjadilah sebuah peristiwa yang sangat mengerikan dan akan mengubah perjalanan hidupnya. Seseorang telah mati dibunuh, dan orang- orang menemukan pisau bersimbah darah di bawah bantal saudagar itu. Dia ditangkap, diadili, dan dijatuhi hukuman seumur hidup, karena telah menghilangkan nyawa seseorang. Semua orang, termasuk sahabat dan keluarganya benar-benar percaya bahwa dia yang berlagak sebagai orang yang berhati mulia ini tidak lain adalah seorang pembunuh. Oleh karena itu, dia harus dijauhi. Maka, di dalam penjara dia tidak pernah dikunjungi siapapun, termasuk istri dan anak- anaknya. Waktu berjalan terus, dan saudagar yang baik ini pun akhirnya menjadi uzur. Oleh karena selama dalam penjara dia selalu menunjukkan perilaku baik, maka dia mendapat remisi untuk dibebaskan. Dia akan keluar, bebas kembali, tetapi akan kemanakah dia pergi. Semua sahabat karib dan keluarganya sudah bercerai-berai, dan andaikata bertemu pun, mereka tidak akan sudi menolong dia, sebab dia tidak lain adalah seorang pembunuh. Tepat pada saat dia meninggalkan penjara karena sudah dibebaskan, seorang yang lain dimasukkan ke dalam penjara. Begitu sang saudagar melihat orang itu taulah dia bahwa orang itu tidak lain adalah pembunuh sebenarnya. Namun, karena sudah lama memaafkan pembunuh yang sebenarnya ini, dia diam, dan sekejab berikutnya dia meninggal. Dia meninggal sebagai seorang pembunuh yang akan dibebaskan dari penjara karena selama di penjara dia selalu berperilaku baik.

Mengapa orang yang begitu mulia hatinya harus kehilangan segala-galanya, termasuk keluargaya sendiri. Pertanyaan ini, ditambah dengan cara Tolstay bercerita dan juga dengan penggunaan bahasanya yang sangat bagus, mau tidak mau akan memancing pembaca untuk merenung, dan pembaca, dengan demikian, terpancing untuk menafsirkan makna cerita pendek ini dari berbagai segi, sebagaimana misalnya, agama, filsafat, hukum, dan lainlain. Biasanya karya sastra yang demikian ini tidak semua orang bisa memahami 
untuk dipahami, dan karena itu pula, sastra jenis ini bisa dikonsumsi oleh siapapun tidak terkecuali kalangan awam.

\section{Cerita Pendek (Cerpen)}

Cerita pendek atau sebagian orang meyamakan dengan novela adalah kisahan pendek (kurang dari 10.000 kata) yang dimaksudkan memberikan kesan tunggal yang dominan (Sujiman, 1990:15). Cerita pendek memusatkan diri pada satu tokoh dalam satu situasi pada satu ketika. Meskipun persyaratan ini tidak terpenuhi, cerita pendek tetap memperlihatkan kepaduan sebagai patokan. Cerita pendek yang efektif terdiri dari tokoh atau sekelompok tokoh yang ditampilkan pada satu latar atau latar belakang dan lewat lakukan lahir atau batin terlibat dalam satu situasi. Inti dari cerita pendek adalah tikaian dramatik, yaitu benturan antara kekuatan yang berlawanan.

Dalam cerita pedek plot atau alur pada umumnya tunggal, hanya terdiri dari satu urutan peristiwa yang diikuti sampai cerita berakhir (bukan selesai, sebab banyak cerpen juga novel, yang tidak berisi penyelesaian yang jelas, penyelesaian diserahkan kepada interpretasi pembaca). Demikian pula penokohan dalam cerita pendek juga terbatas, apalagi yang berstatus sebagai tokoh utama. Selain itu, cerita pendek tidak memerlukan detil-detil khusus tentang keadaan latar. Cerita pendek hanya memerlukan pelukisan secara garis besar saja, atau malahan hanya secara implisit, asal telah mampu memberikan suasana tertentu yang dimaksudkan.

\section{Drama}

Drama adalah bentuk karya sastra yang bertujuan menggambarkan kehidupan dengan mengemukakan tikaian dan emosi lewat lakuan dan dialog (Sujiman,
1990:22). Drama lazimnya dirancang untuk pementasan di panggung.

Seperti halnya novel dan cerpen, drama juga memiliki plot, tokoh dan latar. Hanya saja yang disebut terakhir ini agak berbeda dibandingkan dengan yang disebut kedua sebelumnya. Dalam drama, latar dapat digambarkan secara verbal. Artinya, latar ditunjukkan oleh petunjuk pementasan yang menyangkut dekorasi dan peralatan panggung (Wellek dan Warren, 1993:290).

Masalah utama yang menandai perbedaan antara drama dengan fiksi naratif lain yang menyangkut pengarang adalah: pengarang pada drama menghilang di belakang layar. Maksudnya, pengarang sudah tidak lagi terlibat langsung dalam pementasan. Semua yang diskenario telah dijalankan oleh pelaku-masing-masing dengan kemampuan acting masing-masing pula. Bahkan, kadang-kadang pelaku dapat menambah atau mengurangi tampilan dalam acting dari tampilan yang telah diskenario oleh pengarang. Penambahan dan pengurangan tampilan dalam acting sama sekali tidak mengurangi isi dari skenario yang dibuat, justru dapat menambah keadaan lebih sesuai atau serasi.

Drama disebut juga sebagai fiksi naratif yang mengikuti metode objektif. Keobjektifannya terletak pada absennya sang pengarang dari prosesi panggung yang dibawakan oleh para pelaku dalam drama tersebut (Wellek dan Warren, 1993:295).

\section{SIMPULAN}

Karya sastra yang berbentuk fiksi naratif dianggap sebagai karya sastra mimesis, karena menampilkan tiruan kenyataan dari suatu peristiwa. Kendati kebenaran yang dimiliki bergantung dari sudut pandang pengarang, tetapi kebenaran fiksi naratif merupakan 
kebenaran berupa sindiran kenyataan yang amat dalam dari kecerdasan pengarang menangkap makna kehidupan. Menurut Saini (1990) untuk menjelmakan kreativitas, diperlukan dua unsur yang tidak dapat dipisahkan, yaitu kesadaran manusia yang berupa kepekaan, pikiran, perasaan dan hasrat, dan yang kedua realita yang berupa rangsangan-rangsangan, dan masalahmasalah yang melingkupi, dan yang senantiasa menggiatkan kesadaran manusia. Dua alasan itu cukup dapat meyakinkan bahwa karya-karya sastra yang diwujudkan oleh para pengarang, bukanlah karya-karya yang ngawur. Oleh karena itu, karya-karya sastra berupa fiksi naratif ini sering disebut sebagai bentuk kritik yang santun.

Kumpulan cerpen karya M. Shoim Anwar yang tersaji dalam cerpen Pot dalam Otak Kepala Desa, Musyawarah Para Bajingan, dan Oknum dianggap sebagai simbul perlawanan terhadap kekuasaan. Kritik terhadap ketimpangan ekonomi, sosial, hukum dan lain-lain dapat diperankan melalui karya-karya berupa fiksi naratif dari para pengarang yang cerdas dan peka terhadap hidup dan kehidupan.

\section{DAFTAR PUSTAKA}

Darma, Budi. 2004. Pengantar Teori Sastra. Jakarta: Pusat Bahasa.

Keraf, Gorys. 1985. Argumentasi dan Narasi. Jakarta: PT Gramedia.

Luxemburg, Jan Van. 1989. Pengantar Ilmu Sastra. Jakarta: PT Gramedia

Nurgiatoro, Burhan. 2005. Teori Pengkajian Fiksi. Yogyakarta: Gajah Mada University Press

Sujiman, Panuti. 1990. Kamus Istilah Sastra. Jakarta: Penerbit Universitas Indonesia.

Saini K.M. Apresiasi Kesusastraan. Jakarta: PT Gramedia Pustaka Utama.

Wellek, Rene \& Austin Warren. 1993. Teori Kesusastraan. Jakarta: PT Gramedia. 